\title{
DE ALGUNAS NOVELISTAS DOMINICANAS Y TOEYA DE VIRGINIA DE PEÑA DE BORDAS
}

Giovanni di Pietro*

Todavía queda por escribir la historia de las novelas dominicanas escritas por novelistas femeninas. Se menciona siempre, no importa la ocasión, a Aída Cartagena Portalatín y su Escalera para Electra, novela que estuvo casi a punto de ganar un premio internacional de mucho prestigio. De esta autora también tenemos otra novela, La tarde en que murió Estefanía. Se oye hablar de Hilma Contreras, de su La tierra está bramando, que algunos consideran una novela bien hecha. Hay, sin embargo, otras novelistas, algunas de las cuales, como por ejemplo Ludín Lugo, totalmente desconocidas, o, como Carmen Stengre, quizás justamente olvidadas. Y tenemos, además, el caso de Virginia de Peña de Bordas, autora de la fantasía indigenista Toeya, su única novela, postumamente publicada en 1949 y reeditada dos veces, 1952, en Barcelona, y 1978, en Santo Domingo. En 1978 salió también Seis novelas cortas; pero, a pesar del título, lo que en ese tomo se reune nada tiene que ver con la novela en el sentido estrícto de la palabra.

$\mathrm{Si}$, como hemos notado en muchos lugares, el campo de la novelística dominicana contemporánea está en un horrendo descuido, y con esto nos referimos a los novelistas masculinos, iimagínense el descuido que puede haber en la rama femenina de ese miso campo! Tanto de los novelistas como de las novelistas se escriben cosas que confinan con el absurdo, se tienen preferencias injustificadas y se emiten juicios críticos que, al analizarlos de cerca, simplemente no resisten un serio escrudriñamiento.

Veamos algunos ejemplos. Mucho se ha escrito acerca de la novela de Cartagena Portalatín, Escalera de Electra. El caso del casi galardón internacional ha creado alrededor de esa novela una aureola de infalibilidad en términos de excelencia estética. Todos siempre se refieren a

* Facultad de Humanidades, UASD. 
ella como a una gran novela, una de las mejores obras en la novelística contemporánea tanto en el país como fuera. Pero, ¿por qué? ¿Qué tan buena es? Indudablemente, Escalera para Electra tiene sus puntos fuertes. A nadie se le ocurriría restárselos. Sin embargo, a distancia de tiempo por su aclamación en el foro literario internacinal, es obvio que hay que preguntarse cuál sería su valor actual. Por ejemplo, ino suena un poco vacío en el presente el tema del incesto, ese tema que al aparecer por privera vez en la novelística dominicana no podía hacer otra cosa que crear un furor? ¿Era ese un tema sentido por la escritora o es que se lo impuso a sí misma? ¿Cuál sería la relación entre ese tema y la sociedad dominicana? Porque está claro que ese volver a la tragedia griega, aunque tuviera sentido para Portalatín, no es exactamente una feliz elección. Todo ese procedimiento de narrar la historia de Electra por parte de una amiga super-intelectual que supuestamente la conocía en vida y que se encuentra ahora, iextraño caso!, en Grecia, es decir, en la tierra del mito del incesto, nos aparece ahora, sin duda alguna, un tanto forzado.

Ni hablar de La tarde en que murió Estefanía. Si es una novela en versos no es exactamente claro. Además, para todos aquellos que la leen con detenimiento, es clarísimo el hecho de que como novela no tiene mucho que ofercernos. Tenemos nuevamente el tema del incesto -esta vez entre hermanos. Está también el tema del dictador. Y Estefanía, de ser una simple camarera en un hotel, se ve -y esto podía ocurrir de esa manera sólo en la mente dé la autora-transformada de la noche a la mañana en una codiciada modelo internacional. Con tantas cosas disparadas juntas, más el dilema de si es o no una novela en versos, podemos ver que La tarde en que murió Estefanía no podía ser otra cosa que un lamentable fracaso literario.

De la Aída Cartagena Portalatín de Escalera para Electra, con todas sus fallas, a la Hilma Contreras de La tierra está bramando hay una diferencia abismal. La tierra está bramando es una aburridísima colección de páginas que no llevan a nada. La temática de la dictadura y de las luchas estudiantiles, junto a la otra de un amor que no se consume, simplemente no se traducen en personajes y situaciones válidas que puedan levantar esas páginas al nivel de una novela, ni siquiera mediocre.

Previamente hemos dedicado un ensayo al análisis de la novela de Ludín Lugo, El caballero de la ciudad. He ahí una novela de verdad, y 
eso a pesar de su excesiva extensión y a veces pesado movimiento. Sin embargo, ¿quién conoce esta novela? Frente a Escalera para Electra, La tarde en que murió Estefanía y La tierra está bramando, a nuestro entender El caballero de la cindad tiene una primacía incuestionable. Lugo tiene algo que contarnos y lo hace. No tiene nada de las preocupaciones intelectuales de Cartagena Portalatín o Contreras, y es ésta la clave del éxito de su novela.

Carmen Stengre tiene a su cargo la novela ¿Y mañana...?, publicada en 1944. Lo que se publicó con el título de Hermana Violeta no son novelas cortas, sino simples cuentos. La preocupación de Stengre, su idée fixe -diríamos-, es el tema de la guerra. La guerra es destrucción, muerte, crueldad, injusticia, destierro, etc., y, por consiguiente, la humanidad tiene que aprender a vivir en paz. ¿Cómo? Renunciando a la guerra, viéndola por lo que es. Para lograr esto, Stengre da a la mujer un papel estelar. Es la misión de la mujer -y muy especialmente de la mujer como madre- sacrificarse a fin de que los hombres entiendan que la paz es preferible a la guerra. Sale de eso, en efecto, la imagen de la Hermana Violeta del cuento homónimo. Como el personaje de Violeta, la mujer de Stengre no es un ser débil, sino uno dotado de un carácter fuerte que se impone a las circumstancias y logra el resultado que se propone lograr. En la novela iY mañana...?, Stengre tiene páginas y situaciones que valen la pena; es una lástima, pues, que, en su conjunto, la novela no llega a ser lo que prometía ser. Quizás su novela esté justamente olvidada, pero no se debería olvidar el nombre de Stengre en la historia de la novela dominicana.

Esto es así porque, al mirar a las novelistas dominicanas, nos damos cuenta de que en sus cuentos y su novela Stengre introduce por primera vez una determinada imagen de la mujer en la novela dominicana. Podríamos tachar de superficial y de irreal la misión que en su obra Stengre da a la mujer. Después de todo, ya que se trata de aquel período de resaca sentimental que fueron los años entre 1918 -fin de la Primera Guerra Mundial- y 1936 -inicio de la postura beligerante de las dictaduras con la guerra civil española-, esta imagen es algo muy tradicional, casi a la moda. Pero, como hemos dicho, la mujer que Stengre nos da no es una mujer pasiva. Su pacifismo hace parte tanto de su sicología fundamental como de aquel rol tradicional que a la mujer se le asignaba. Sin embargo, la nota, el elemento nuevo que Stengre introduce, tiene que ser subrayado: la imagen de la mujer que ella nos brinda es la de 
una mujer que lucha activamente para realizar un mundo en el cual tanto el hombre como ella puedan tener una vida feliz que sea digna de vivir en libertad. Por eso, aunque ¿Y mañana...? fracase como novela, salvable es el personaje de Martha, mujer, esposa y madre que muere enfrentándosele a la inhumana crueldad de los nazi. Antes de Stengre, en la novelística dominicana contemporánea, ¿quién había presentado un personaje femenino con tales características? El personaje de Martha, de hecho, es preferible a los más actuales -pero falsos- personajes de Electra, Estefanía y Genita en las novelas de Cartagena Portalatín y Contreras. Como mujer luchadora, Martha es un personaje que dentro de la novelística dominicana contemporánea encontraremos nuevamente sólo en El Caballero de la ciudad, de Lugo.

Asíque hemos llegado a Virginia de Peña de Bordas, a sus supuestas Seis novelas cortas y su Toeya.

No vamos a negar que, al encontrarnos con las novelas de de Peña de Bordas, la idea de leer una "fantasía indigenista" no nos fue muy alagadora. Nos lo imaginábamos un tollo literario sin ninguna duda. Fue muy grata, pues, la sorpresa de descubrir en Toeya una novela que, si no exactamente de primera categoría, muy bien vale la pena leerla y reeditarla para que sea leída.

Han sido muchas las aclamaciones que esta novela de de Peña de Bordas ha recibido desde su primera publicación en 1949. Sin embargo, no se nos debería escapar el hecho de que esas aclamaciones, como por ejemplo las que se incluyen en el apéndice de la edición de 1978, aunque sinceras, son casi siempre emitidas de pasada y por personas que poco tienen que ver con el ejercicio de la crítica literaria. Es imprescindible, pues, pasar de este tipo de tributo extraliterario a un tributo de carácter puramente literario, algo que, por lo menos en cuanto a su novela Toeya, esta autora indudablemente se merece más de la cuenta. Esta sería en el futuro una de las obligaciones que la crítica literaria tendría en el campo de la novelística nacional.

Nosotros no vemos con buen ojo a las Siete novelas cortas. Como hemos dicho, ellas no son novelas; son cuentos. En cuanto tales, hay que establecer claramente cuál sería su valor literario. En el lenguaje y en las situaciones y hasta en los personajes estos cuentos tienen un resultado feliz. Sin embargo, no podemos darles una aclamación crítica porque, a bien mirarlos, estos cuentos tienen poco que ofrecernos. Es fácil ver en ellos la extensión social de la personalidad de la escritora. 
El ambiente selecto, los personajes adinerados, el refinamiento aristocrático, el deseo de sobresalir socialmente... Todo esto nos deja sin cuidado. Claro está, éste era el mundo social en el cual de Peña de Bordas se movía; era, además, el mundo de los años treinta y cuarenta, años en los cuales las castas altas dominicanas -a las cuales la autora pertenecía-, viviendo en confabulación con la dictadura, todavía experimentaban una vida idílica cerrada a los sinsabores sociales, económicos, políticos y morales. "All's well that ends well," podríamos decir de estos cuentos. En el medio de este ambiente rico y aristocrático, el personaje de la muchacha bien educada, blanca y pura encuentra siempre aquel príncipe azúl que soñaba desde niña, sea éste su primo, su vecino, o un caballero exótico que llega justo a tiempo para salvar su dicha y su honor. Este es un mundo en el cual el lector puede penetrar sólo de una manera vicaria. A menos que él mismo no haga parte de ese mundo, se sentirá excluido, un intruso. Es un ambiente de cuentos de hadas en el cual la entrada depende únicamente del pasaporte de riqueza y buenos modales en términos de casta social que tenemos.

Dicho esto, creemos, sin embargo, que es injusto acusar a Virginia de Peña de Bordas de haber creado tal mundo con la clara intención de excluír la chusma de él. Ella escribía sobre el ambiente que era suyo y que conocía. Este ambiente, se ve de los mismos cuentos, aunque pareciera ideal no lo era. En todos esos cuentos hay una obsesión por parte de su autora de querer creer en cuentos de hadas, y esto como para excluir conscientemente de su ángulo visivo lo que sería la inevitable presencia del mal. De modo que, al mirarlos bien, lo que en estos cuentos está en juego es la lucha entre el bien y el mal, con el bien -amén de ser siempre un adinerado príncipe azúl-constantemente triunfador. En el mal está el dolor; en el bien, la dicha. Como una niña mimada o como un ser que sufre mucho, Virginia de Peña de Bordas anhela vivir en un mundo sin dolor, en un mundo hecho sólo del bien, y esto porque, por muchas razones que son propias de la personalidad de una niña mimada y de una persona que sufre mucho, ella, en su fuero interno, no experimenta ese mundo, no lo conoce, aunque tọdo en su ambiente la condiciona, claro está, a creer lo contrario.

Esta dinámica de la lucha entre el bien y el mal en términos de dicha y de sufrimiento la encontramos también en Toeya, pero sin ese mundo asfixiante del ambiente selecto y rico que daña los cuentos de Seis novelas cortas. 
Como todas las historias de Seis novelas cortas, también la de Toeya es una historia de amor. Toeya, aparte de su indigenismo, del cual mucho en ella se habla, y aparte de la reconstrucción del ambiente histórico -la corte de los Virreyes, el Santo Domingo colonial-, funciona esencialmente a nivel de historia de amor. Toeya, la desdichada princesa india, y don Juan, desafortunado segundogénito, pintor y futuro marqués de Sotomayor, son personajes del mundo de los cuentos de Seis novelas cortas trasladados al período de los orígenes de la nación dominicana. Don Juan, en Toeya, sería aquel príncipe azúl que llegaría para salvar a la pobre y desdichada princesa. Pero, a despecho de todas las buenas intenciones de la autora, esta vez el cuento de hadas que fuera de las Seis novelas cortas no funciona, y todo en la historia de amor entre estos dos personajes termina en la tragedia: muere Toeya, muere la posibilidad de su raza de levantarse con dignidad mediante la ayuda de los españoles bienintencionados (uno de los roles de don Juan) y muere en su amor el propio príncipe azul, don Juan, cuyo resonante título de marqués de Sotomayor y cuyos desbordantes cofres no lo salvarán de la desdicha. "Amor vincit omnia", este es la fórmula con que Toeya inicia. En Seis novelas cortas, esta fórmula siempre tiene buen éxito. Sus personajes ricos, opulentos, cultos y sensitivos hasta el extremo ganan su batalla en contra del mal y logran alcanzar lo que sería para ellos su destino normal, el de la dicha. No es así en el caso de Toeya. En esta novcla este mismo tipo de personajes aprenden la ruda lección de la vida: que ella no está hecha necesariamente de un destino feliz, que por alguna inexplicable razón este destino puede terminar en una tragedia total. De que el amor venza todo es una verdad de los cuentos de hadas, pero la vida, esa vida que tanto palpita en las hermosas páginas de Toeya, no es ningún cuento de hadas. Esta es la lección que Virginia de Peña de Bordas nos da con su novela. Y es como si esta lección, fin de cuentas, ella se la estuviera dando a sí misma, ya que su propia vida -como sabemos- no terminó exactamente de la misma manera en que termina un cuento de hadas. Es como si esa obstinación que hay en sus cuentos y que termina en el trágico final de Toeya de lograr la felicidad fuera una premonición de aquella muerte a destiempo de la cual la autora pereció. La dicha, por supuesto. Y, en Toeya, de Peña de Bordas busca esta dicha. Sólo que, como en su muerte, es el dolor que al final triunfa.

Sin embargo, al terminar de leer Toeya sabemos que esto no es lo que la escritora quería. Nos sentimos como ella defraudados. La vida, es decir, el destino, ha defraudado a la virgen Toeya y al artista don Juan. 
El mal gana su batalla en los ojos llenos de odio del indio Umatex. Pero no es la última batalla. El bien vive en el corazón de Urabanex, en el de don Juan y los de sus primas, en las buenas intenciones de doña María de Toledo, en el recuerdo mismo de la princesa Toeya, heroína de un mundo que por ironía de la suerte no pudo surgir.

De modo que con Toeya, con esta novela que se hace leer y deberíase leer, y a la cual se debe asignar un lugar estelar dentro de la novelística dominicana contemporánea, Virginia de Peña de Bordas pasa del mundo romántico-sentimental de sus cuentos al mundo trágico (y verdadero) que ya se le revelaba como el posible tema y ambiente de obras futuras que lamentamos nunca tuviese la oportunidad de escribir.

\section{LITERATURA CITADA}

Cartagena Portalatín, Aída. Escalera para Electra. Santo Domingo, Taller, 1975.

La tarde en que murió Estefanía, Ibid., 1983.

Contreras, IIilda. La tierra está bramando. Santo Domingo, Biblioteca Nacional, 1986. Lugo, Ludín. El caballero de la Ciudad. Santo Domingo, Taller, 1981.

Stengre, Carmen. Ilermana Violeta. Ciudad Trujillo, Montalvo, s.f.

¿Y mañana...? Ibid., 1944.

De Peña de Bordas, Virginia, Toeya. Santo Domingo, Taller, 1978.

Seis novelas cortas. Ibid., 1978. 